DOI: $10.17805 /$ zpu.2015.3.5

\title{
Особенности проявления этнической толерантности в малых социальных группах в моно- и полиэтничном регионах России *
}

\author{
Н. С. ГАДЖИГАСАНОВА \\ ( ЯРОСЛАВСКИЙ ГОСУДАРСТВЕННЫЙ УНИВЕРСИТЕТ ИМ. П. Г. ДЕМИДОВА), \\ Н. Г. ХАЙРУЛЛИНА \\ (ТЮМЕНСКИЙ ГОСУДАРСТВЕННЫЙ НЕФТЕГАЗОВЫЙ УНИВЕРСИТЕТ)
}

Российская Федерация характеризуется полиэтничной структурой населения, в которой насчитывается более 180 этносов и входящих в них этнических групп. Одним из важных условий перспективного развития поликультурного социума является мирное сосуществование различных этносов и их представителей. Тем самым определяется необходимость и значимость проявления культуры этнической толерантности среди представителей всех российских народов, а также обусловлена актуальность научного изучения проблемы толерантности. Статья посвящена описанию и анализу этнонациональных отношений, а также государственной политики в данной сфере.

В настоящее время законодательство страны в сфере регулирования национальных отношений характеризуется существенными нововведениями. Приняты и реализуются Стратегия государственной национальной политики Российской Федерации на период до 2025 г.; ФЦП «Укрепление единства российской нации и этнокультурное развитие народов России (2014-2020 гг.)», План мероприятий по реализации в 2013-2015 гг. Стратегии государственной национальной политики Российской Федерации на период до 2025 г. и др. Документы закладывают основу современной государственной национальной политики, нацелены на получение результата в долгосрочной перспективе, но при этом характеризуются фрагментарностью, нуждаются в координировании основных задач, направлений и соответствующих им эффективных способов, механизмов реализации.

В статье приводятся результаты социологического исследования «Особенности проявления этнической толерантности в моно- и полиэтничном субъектах РФ», осуществленного авторами в январе - октябре 2014 г. в Ярославской и Вологодской областях, а также в Республике Дагестан.

Отмечается, что для решения современных проблем в сфере межэтнических отношений целесообразны дальнейшее усовершенствование основополагающих положений нормативных правовых актов, отражающих государственную национальную политику

* Работа выполнена при поддержке гранта Президента РФ МК-1080.2014.6 (проект «Культура толерантности как фактор гармонизации межэтнических отношений»).

The article was prepared as part of the project "Culture of Tolerance as Factor of Harmonization of the Interethnic Relations" (supported by a Grant of the President of the RF, No. MK-1080.2014.6). 
Российской Федерации, анализ соответствия ключевых индикаторов региональных, муниципальных документов (программ) субъектов РФ основным правовым положениям федерального уровня, популяризация культурного наследия страны и др.

Ключевые слова: этническая толерантность, межэтническое взаимодействие, национальная политика.

\section{ВВЕАЕНИЕ}

$\mathbf{R}$ опрос о межэтнических взаимоотношениях народов России во многом связан

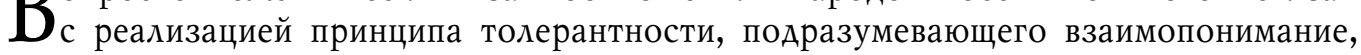
признание независимости и ценности представителей других этносов, а также согласование самых разных установок, ориентаций и мотивов жизнедеятельности представителей различных этнических групп. Усвоение и распространение этого принципа является важнейшим условием перехода к новым общественным взаимоотношениям, позволяющим различным этносам открывать новые проблемные области, обретать новые силы для решения задач успешной трансформации российского общества.

В названных обстоятельствах представляется целесообразным, во-первых, дать историко-теоретическое обоснование понятия «толерантность»в социологической теории, во-вторых, осмыслить понятие «этническая толерантность», в-третьих, преАставить результаты авторского социологического исследования, отражающие особенности проявления этнической толерантности в представлениях жителей моно- либо полиэтничного региона.

\section{РАЗВИТИЕ СОЦИОАОГИЧЕСКИХ ПОАХОАОВ К СУЩНОСТИ ТОАЕРАНТНОСТИ}

Социологический анализ понятия «толерантность» впервые представлен в трудах зарубежных социологов XIX в. По мнению К. Маркса, история человечества - история постоянно растущего отчуждения человека. Специфической особенностью царства отчуждения является то, что сферы жизни в нем не связаны между собой (экономика с моралью и т. А.): каждый вращается в кругу своей собственной отчужденности, и никого не трогает отчужденность других людей (чужая боль). Соответственно, в обществе в целом развивается интолерантность. Источник социальной интолерантности связан с социально-экономическими условиями существования человека. Сформулировав концепцию отчуждения как источника социальной интолерантности, К. Маркс одновременно предложил теорию ее преодоления посредством революционного изменения отношений собственности (Маркс, 2000).

Толерантность (интолерантность) проявляется в процессе социального взаимодействия индивидов. Проблему человеческого взаимодействия как родового социального явления раскрывал в своих работах П. Сорокин. Под взаимодействием автор понимал «любое действие, с помощью которого один человек полуосязаемым путем влияет на открытые действия или состояния ума другого» (Сорокин, 1992: 33). В работе «Человек. Цивилизация. Общество» П. Сорокина отмечается, что взаимодействие между индивидами той же расы, национальности, племени, территориальной группы, семьи и т. А., и особенно между теми, кто обладает идентичными социокультурными ценностями, не аналогично во многих отношениях взаимодействию между индивидами, которые расходятся по этим качествам. Многообразные отношения взаимодействующих участников П. Сорокин сводит к четырем главным формам: тем, которые оказывают влияние просто через знание о существовании участника или участников взаимодействия (каталектическая форма); через совершение открытых дейст- 
вий; через воздержание от открытых действий; через активную толерантность. В целом, по мнению ученого, толерантность может требовать весьма серьезного внутреннего усилия, часто гораздо более серьезного, чем требуется для открытых действий (Сорокин, 1992).

Р. Мертон поставил под сомнение принцип функционального единства социальной системы (в концепции социальной теории Т. Парсонса), открыв возможность для построения более гибких социальных теорий, что позволило сформировать представление об амбивалентности толерантности, о возможности формирования толерантной установки посредством различных социальных механизмов в различных культурах, а также выдвигает на первый план проблему межкультурного толерантного взаимодействия, для разрешения которой модернистская социологическая теория не имеет разработанных теоретических средств (Мертон, 1994; см. также: Аебедева, 2010).

В рамках концепции символического интеракционизма, к представителям которого относят Аж. Г. Мида и Ч. Х. Кули, исследование толерантности возможно не только на уровне личности, но и на уровне социальных групп (Мид, 2009; Кули, 2000; см. также: Козер, 2006). Также концепция интеракционизма весьма эффективна для изучения некоторых аспектов этнических отношений и взаимодействий. Во-первых, учет сложности видения и идентификации людьми самих себя важен при изучении так называемых этнических аномалий или этнокультурных маргиналов. Идентификация как процесс и факт самоопределения может не совпадать с категоризацией, т. е. определением со стороны. Во-вторых, принятие «ситуативной перспективы» делает возможным трактовать появление новых форм идентичности или «этничностей по соглашению» как нормальную черту любого мультиэтнического общества, что действительно подтверждается реальной социальной практикой во многих частях мира. В-третьих, поскольку анализ идентичности как ситуативного конструкта основывается на процессе коллективного определения, то с его помощью можно предвидеть изменения в самоопределении әтнических групп как важную особенность коллективной жизни (Абельс, 1999).

Согласно позиции Р. Парка главной задачей и функцией общества является социальный контроль, который служит для упорядочения разных форм конфликта и конкуренции (Парк, 2011; см. также: Козер, 2006). Однако социальный контроль никогда не может обеспечить постоянный порядок в обществе, поэтому исследователь считал, что устойчивый социальный порядок достигается путем приспособления (аккомодации). Приспособление может быть временным между отдельными индивидами и группами, однако полная аккомодация в современном обществе «никогда не сможет быть постоянной, поскольку могут появиться новые группы и индивиды и потребовать своей доли ограниченных ценностей, тем самым ставя под сомнение порядок вещей, возникший в результате предыдущих приспособлений» (Козер, 2006: 278). Следовательно, общество не может быть всегда толерантным, и, возможно, единственный способ достичь согласия - это аккомодация, которая способна прекратить конфликты и закрепиться с помощью законов, норм и нравственного поведения членов общества.

Аля осмысления сложностей динамики толерантности и интолерантности в современном обществе важное значение имеет выявленная 3. Бауманом диалектика двух основных социальных тенденций, проявляющихся в настоящее время. Согласно Бауману стремления современных людей разрываются между двумя потребностями: потребности в причастности и в индивидуальности. Первая потребность заставляет людей искать прочные и надежные связи с другими. Аюди выражают эту потребность, 
когда говорят или думают о сообществе или общности. Вторая потребность (в индивидуальности) подталкивает людей к замкнутости, к состоянию, в котором они недоступны воздействиям и притязаниям других, делают то, что считают нужным, оставаясь «самими собой» (Бауман, 2002). Обе потребности действенны и могущественны; давление каждой из них усиливается тем больше, чем меньше она удовлетворена. Вместе с тем чем ближе люди подходят к удовлетворению одной потребности, тем болезненнее чувствуют неудовлетворенность другой. Обнаруживается, что сообщество без личной уединенности напоминает скорее подавление, нежели причастность, а уединенность без сообщества походит на одиночество, а не на бытие «самим собой».

Из теоретических обобщений Баумана можно сделать вывод о том, что установление в обществе культуры, сопричастной толерантности, может - при определенных условиях - порождать дисфункциональные эффекты, вызывать обратную, интолерантную реакцию. Понимающее, толерантное отношение к другому может расцениваться и как посягательство на индивидуальность, на приватное пространство, завоевание которого было одним из достижений общества модерна и которое в настоящее время испытывает постоянное негативное давление по причине высокой плотности информационных и коммуникативных каналов «прозрачного» общества.

Исследователь Н. А. Победа осуществила классификацию определений толерантности по основанию структурной сети. В данной классификации концепт толерантности трактуется в следующих контекстах: 1) модальный стоицизм: принципиальное признание того, что другой имеет «право», иначе - «одобрение различия»; 2) моральный идеал: «благость толерантности как отношения», соотношение; 3) «теория блага» (как общественной значимости и основания толерантности) и прав человека, в том числе права реализовать свой жизненный проект; 4) «баланс суждений»; 5) временный баланс сил между конфликтующими группами и ценностями; 6) способы достижения мирного сосуществования; способ, посредством которого утверждаются другие ценности - свобода, равенство, справедливость; 7) ценность и социальная норма гражданского общества (Победа, 2007: 16).

\section{ПОНЯТИЕ ЭТНИЧЕСКОЙ ТОАЕРАНТНОСТИ}

В отечественном академическом поле существенный вклад в развитие научного знания по проблемам в области этнической толерантности внесли работы А. А. Галкина, А. М. Аробижевой, Ю. А. Красина, И. М. Кузнецова, М. Мацковского, Н. В. Паниной, Е. А. Головахи, В. Н. Петрова, Н. А. Победы, С. В. Рыжовой, В. А. Тишкова и др. По мнению А. А. Галкина и Ю. А. Красина, фундаментом толерантного отношения к частным интересам и мнениям, к группам и индивидам, их выражающим, становится признание естественности и неустранимости из общественной жизни «инаковости» (Галкин, Красин, 2003).

В. Н. Петров отмечает, что социологическое исследование этнической толерантности обнаруживает взаимосвязь этого феномена с условиями ситуации (объективная реальность) и субъективными факторами (субъективная реальность), а также его принадлежность всем компонентам системы социального действия, включающего такие подсистемы, как личность, ситуация действия, сами акты социального действия и взаимодействия. Понимание толерантности в контексте теории социального действия опирается на представление о том, что это свойство принадлежит всем элементам его структуры: потребностям, интересам, находит свое воплощение в идеях (как проекте Авижения к удовлетворению потребностей), мотивах и целях (Петров, 2003). 
И. М. Кузнецов обращает внимание на то, что формирование толерантных межэтнических отношений - это двусторонний процесс, в котором одинаковую важность имеют установки на взаимное понимание, исходящие со стороны как этнических меньшинств, так и этнического большинства (Кузнецов, 2003).

М. Мацковский операционализирует понятие толерантности как определенное качество взаимодействия между субъектом и объектом толерантности, характеризуемое готовностью субъекта принимать социокультурные отличия объекта, включающие в себя внешние признаки, высказывания, особенности поведения и т. А. (Мацковский, 2001: Электронный ресурс).

В социальном качестве трактует толерантность С. В. Рыжова как «основу успешной коммуникации и взаимодействие на основе согласия» (Рыжова, 2008: 22).

Н. В. Панина и Е. И. Головаха считают, что противоречие между групповыми культурными правами и индивидуальными правами снимается в том случае, если человек способен не только идентифицировать себя со «своей» группой, но и распространять механизмы идентификации на другие социальные группы, принимая их представителей как «своих» (Панина, Головаха, 2006). Это утверждение созвучно представлениям $\Lambda$. М. Аробижевой об этнической толерантности как умении принять других как равноправных партнеров и организовать взаимодействие с ними. Вместе с тем Аробижева отмечает, что социологический ракурс рассмотрения межэтнической толерантности ориентирован на выявление социальных и культурных факторов толерантного или нетолерантного взаимодействия (Аробижева, 2009). Согласно трактовке В. А. Тишкова толерантность, в том числе и этническая, - это «уважение или признание равенства других и отказ от доминирования или насилия», «активная позиция самоограничения и намеренного невмешательства» (Тишков, 2003: 313, 315).

На основе обзора интерпретаций концепта «толерантность» необходимо отметить многогранное, амбивалентное и динамичное содержание исследуемого понятия. В этой связи авторы работы трактуют этническую толерантность как систему норм сочиального взаимодействия и отношений $к$ различным проявлениям сочиальнокультурного разнообразия, регулирующих сочиальные связи в различных сфрерах жизни общества.

\section{ГОСУААРСТВЕННАЯ ПОИИТИКА В СФЕРЕ РЕГУАИРОВАНИЯ ЭТНОНАЦИОНААЬНЫХ ОТНОШЕНИИ}

В условиях российской действительности вопросы регулирования межнациональных отношений являются предметом активных обсуждений не только научной общественности, но и всех ветвей государственной власти. В частности, одним из наиболее актуальных подтверждений этому служит и Поручение Президента РФ В. Путина от 13 марта 2015 г. о рассмотрении вопроса и предоставлении предложений о создании Федерального агентства по делам национальностей Председателю Правительства А. Медведеву, а также подписание в достаточно сжатые сроки Президентом РФ Указа «О Федеральном агентстве по делам национальностей» (Поручение по вопросу ..., 2015: Электронный ресурс; Указ Президента РФ ..., 2015: Электронный ресурс). Аля расширения практики конструктивного межэтнического взаимодействия российских народов основополагающими в государственных масштабах выступают такие документы, как Стратегия государственной национальной политики Российской Федерации на период до 2025 г.; постановление Правительства РФ о ФЦП «Укрепление единства российской нации и этнокультурное развитие народов России (2014-2020 гг.)», указы 
Президента РФ «Об обеспечении межнационального согласия», «О Совете при Президенте Российской Федерации по межнациональным отношениям» и др. (Подписан Указ ..., 2012: Электронный ресурс; Образован Совет ..., 2012: Электронный ресурс).

Количественный контент-анализ Стратегии государственной национальной политики Российской Федерации на период до 2025 г. позволил зафиксировать, что в тексте, состоящем из 4752 слов, ключевыми выступили следующие характеристики программы: «являющаяся национальной» / «государственной» $(6,9 \%, 319$ упоминаний), «российская» $(3,8 \%, 181$ упоминаний), «политика» $(1,59 \%, 76$ упоминаний), «при активной роли граждан» $(1,3 \%, 62$ упоминания), «затрагивающая межнациональные интересы» $(0,98 \%, 47$ упоминаний), «реализуемая на муниципальном уровне» $(0,6 \%$, 28 упоминаний) и «имеющая целевой характер» $(0,52 \%, 25$ упоминаний), «для формирования мира» $(0,27 \%, 13$ упоминаний) и «для формирования согласия» $(0,25 \%$, 12 упоминаний). Мы полагаем, что разработчики анализируемого документа, прежде чем возлагать надежды на возможность реализации Стратегии-2025 при непосредственной активной деятельности гражданского общества должны были критически оценить представления самих россиян о гражданской инициативе. Аело в том, что согласно социологическим данным Аналитического центра Ю. Аевады об актуальности самоорганизации общества снизу заявляли в 2013 г. только 10\% респондентов, тогда как более востребованным является согласно мнению $57 \%$ опрошенных обеспечение равенства всех граждан перед законом независимо от места в «вертикали власти», количества денег, национальности (Общественное мнение ..., 2014: 30).

В соответствии со Стратегией к числу приоритетных целей национальной политики РФ отнесены: 1) консолидация общероссийского гражданского самосознания российской нации при условии сохранения и поддержания этнокультурного многообразия народов, проживающих на территории РФ; 2) усовершенствование и гармонизация межэтнических отношений при условии успешной социокультурной адаптации, интеграция мигрантов; 3) соблюдение равенства прав и свобод человека и гражданина независимо от расы, национальности, языка, отношения к религии и иных обстоятельств. При этом отметим, что особенностью Стратегии государственной национальной политики Российской Федерации на период до 2025 г. является непредусмотренность разработчиками в основополагающем документе ожидаемых результатов, что, безусловно, может затруднить как контроль, так и комплексный, объективный анализ ее реализации. Кроме этого, эффективность реализации одной из задач анализируемой Стратегии-2025 в сфере образования, патриотического и гражданского воспитания подрастающего поколения может быть затруднена в связи с отсутствием информации об исходном и прогнозном значении такого индикатора, как степень информированности детей, подростков и молодежи о культуре и национальных традициях народов России. Считаем, что вследствие указанных недостатков сформулированная в документе задача основана на формальном подходе и носит номинальный характер.

В качестве инструмента реализации Стратегии государственной национальной политики Российской Федерации на период до 2025 г. и госпрограммы РФ «Региональная политика и федеративные отношения» (Распоряжение Правительства ... , 2013: Электронный ресурс; Постановление Правительства ... , 2014: Электронный ресурс) на федеральном уровне принята Федеральная целевая программа «Укрепление единства российской нации и этнокультурное развитие народов России (2014-2020 гг.)», которая предполагает переход от ситуативной поддержки отдельных мероприятий в субъектах страны к программно-целевому методу комплексной реализации государ- 
ственной национальной политики на территории всей страны, цель которой в укреплении единства многонационального народа РФ (российской нации). Среди важнейших целевых индикаторов данной программы присутствует в числе других «доля граждан, положительно оченивающих состояние межначиональных отношении, В общем количестве граждан Российской Федерачии» (курсив наш. - Н. Г., Н. Х.) (Постановление Правительства ..., 2013: Электронный ресурс).

Между тем на основе анализа содержания документа ФЦП «Укрепление единства российской нации и этнокультурное развитие народов России (2014-2020 гг.)» мы пришли к выводу, что в методике расчета одного из целевых индикаторов данной федеральной программы содержится формула, которая априорно нацелена на искажение информации о доле российских граждан, положительно оценивающих состояние межнациональных отношений. Аело в том, что авторы программы для расчета указанного показателя рекомендуют суммировать два показателя: количество граждан, признавших, что за последние годы межнациональные отношения в России стали более терпимыми, и количество граждан, признавших, что за последние годы межнациональные отношения в России не изменились. Однако мы считаем, что данные показатели неравнозначно интерпретируют атмосферу межнациональных отношений в российском обществе, поэтому приравнивать мнения тех, кто отметил положительную динамику, с точкой зрения о константном характере межэтнической ситуации как минимум дискуссионно. Также мы выявили, что в Стратегии-2025 в рамках задачи по содействию национально-культурному развитию народов предусматривается формирование в обществе атмосферы уважения к историческому наследию и культурным ценностям народов России. Однако в Плане мероприятий по реализации в 2013-2015 гг. Стратегии государственной национальной политики РФ на период до 2025 г. совершенно не предусмотрена организация посещения различными категориями и группами населения музеев (как федеральных, так и региональных, муниципальных), национальных культурных центров субъектов РФ, что минимизирует реализуемость поставленной задачи. Единственным исключением является запланированное проведение международного фестиваля музеев «Интермузей» (2013-2015) (во исполнение Указа Президента Российской Федерации от 7 мая 2012 г. № 602 «Об обеспечении межнационального согласия»), представляющего собой в большей степени профессиональное мероприятие соответствующих культурных учреждений с целью развития межрегиональных связей.

На основе изложенного считаем своевременным конструктивно, системно, поступательно подойти к усовершенствованию основополагающих положений нормативных правовых актов, отражающих государственную национальную политику РФ на современном этапе: Стратегии государственной национальной политики Российской Федерации на период до 2025 г., Плана мероприятий по реализации в 2013-2015 гг. Стратегии государственной национальной политики Российской Федерации на период до 2025 г., Федеральной целевой программы «Укрепление единства российской нации и этнокультурное развитие народов России (2014-2020 гг.)» - с целью преодоления фрагментарности, согласования основных задач, приоритетных направлений, показателей и соответствующих им әффективных способов, механизмов реализации. Наряду с этим для достижения этой же цели считаем, что предстоит анализировать и соответствие ключевых положений, индикаторов региональных, муниципальных документов (программ) субъектов РФ основным положениям нормативных правовых актов федерального уровня. 


\section{ИССАЕАОВАНИЕ В ЯРОСААВСКОЙ, ВОАОГОАСКОЙ ОБААСТЯХ И ААГЕСТ АНЕ 2014 Г.}

С целью исследования особенностей проявления этнической толерантности в малых социальных группах в январе - октябре 2014 г. в моноэтничных субъектах (Ярославской и Вологодской областях), а также в полиэтничном регионе (Республике Аагестан) - был проведен анкетный опрос 1200 жителей указанных регионов, отобранных по квотной выборке. Выборка статистически репрезентативна в разрезе этнической принадлежности, социально-демографических характеристик респондентов, а также территориального распределения взрослого населения регионов. Выбор Ярославской и Вологодской областей объясняется прежде всего тождественным этническим составом населения: оба региона можно назвать практически моноэтничными, так как русские на момент Всероссийской переписи населения 2010 г. составляли $96,0 \%$ и 97,27\% соответственно. Общая численность населения также свидетельствует о сходстве: 1272468 чел. в Ярославской области, 1202444 чел. - в Вологодской. Кроме того, приток мигрантов и в тот, и в другой регион практически идентичен как по количественным, так и по качественным показателям (число мигрантов, уровень образования, возрастной состав, национальность, гражданство и т. п.). В то же время интерес к Республике Аагестан обусловлен исторической мозаичностью этнического состава населения, уникальным опытом поддержания гармонии в межэтнических отношениях. По данным Территориального органа Федеральной службы государственной статистики по Республике Аагестан, по результатам Всероссийской переписи населения 2010 г. численность населения составила 2 млн 910,2 тыс. чел. В республике насчитывается восемь наиболее многочисленных национальностей, численность которых превышает 100 тыс. человек. Считаем, что привлечение в эмпирическое исследование представителей этнических групп, длительно проживающих в отличающихся по этнической структуре субъектах РФ, обнаруживает значимые различия в субъективных оценках этнофоров по данному вопросу и позволяет нам достигать заявленных в работе задач.

Задачами исследования обозначены следующие:

- проанализировать особенности, детерминирующие реализацию этнической толерантности в малых социальных группах;

- охарактеризовать мнения респондентов о перспективной возможности социализации молодого поколения на основе уважения к другим людям и доброжелательности;

- выявить мнения опрошенных об интеграционном потенциале толерантных практик сквозь призму анализа опыта межэтнического взаимодействия;

- изучить этноинтегрирующие и этнодифференцирующие компоненты общероссийской консолидации / дезинтеграции народов в самосознании жителей регионов.

На наш взгляд, начать рассматривать характеристики, которые влияют на проявления этнической толерантности в малых социальных группах, можно с анализа альтернатив в процессе усвоения подрастающим поколением определенной системы знаний, норм и ценностей, позволяющих им функционировать в качестве полноправных и при этом толерантных членов общества. Операционализируя толерантность как систему норм социального взаимодействия и отношений к различным проявлениям социально-культурного разнообразия, регулирующих социальные связи в различных сферах жизни общества, мы обратились к респондентам с вопросом: «Какие из ириведенных качесть, по вашему мнению, важно прививать ребенку в прочессе воспита- 
ния? ». Нам удалось выяснить, что, по мнению респондентов, чаще всего необходимо акцентировать внимание в процессе социализации на воспитании честности $(21,3 \%)$, трудолюбия $(16,3 \%)$, а также вежливости $(14,6 \%)$ и уважения к другим людям $(14,2 \%)$. Вариант ответа «важно прививать ребенку покорность» оказался в числе наименее популярных $(2,1 \%)$ (табл. 1).

Таблица 1

РАСПРЕАЕ АЕНИЕ ОТВЕТОВ НА ВОПРОС «КАКИЕ ИЗ ПРИВЕАЕННЫХ КАЧЕСТВ, ПО ВАШЕМУ МНЕНИЮ, ВАЖНО ПРИВИВАТЬ РЕБЕНКУ В ПРОЦЕССЕ ВОСПИТАНИЯ?»

Table 1

DISTRIBUTION OF ANSWERS TO THE QUESTION “WHICH OF THE FOLLOWING QUALITIES SHOULD A CHILD DEVELOP IN THE COURSE OF EDUCATION?”

\begin{tabular}{|l|c|c|}
\hline \multicolumn{1}{|c|}{$\begin{array}{c}\text { B прочессе воспитания } \\
\text { Важно прививать ребенку... }\end{array}$} & $\begin{array}{r}\text { Om числа ответов } \\
\text { респондентов, в \% }\end{array}$ & $\begin{array}{r}\text { От числа } \\
\text { респондентов, в \% }\end{array}$ \\
\hline Честность & 21,3 & 70,5 \\
Трудолюбие & 16,3 & 54,0 \\
Вежливость и воспитанность & 14,6 & 48,3 \\
Уважение к другим людям & 14,2 & 46,8 \\
Аоброжелательность & 11,1 & 36,8 \\
Хорошие манеры & 10,2 & 33,6 \\
Самоконтроль & 10,2 & 33,6 \\
Покорность & 2,1 & 6,8 \\
Всего & 100,0 & 330,5 \\
\hline
\end{tabular}

Примечание: предполагалась возможность нескольких вариантов ответов.

При этом если на необходимость уделять внимание формированию честности указывают как мужчины, так и женщины вне зависимости от возраста, но при этом люди со средним уровнем образования $(72,4 \%)$ и малообеспеченные респонденты $(77,0 \%)$, большинство представителей этнических групп Аагестана - кумыки (92,0\%), аварцы $(85,0 \%)$ и даргинцы $(73,7 \%)$, то на актуальности социализации в духе вежливости и воспитанности сосредоточили внимание респонденты в возрасте до 30 лет $(48,6 \%$ юношей и 54,5\% девушек) с общим средним образованием (52,1\%), а также чаще даргинцы $(77,4 \%)$, лезгины $(73,7 \%)$ либо азербайджанцы $(73,7 \%)$. На важность воспитания в детях уважения к другим людям чаще указывают представители азербайджанской $(65,3 \%)$ и аварской этнических групп (53,3\%), девушки в возрасте от 18 до 22 лет (52,9\%), респонденты, которые, как было выяснено специально, не имеют опыта демонстрации личной неприязни к людям ввиду этнических различий $(51,2 \%)$, опрошенные со средним общим образованием (50,7\%), среднеобеспеченные респонденты $(48,2 \%)$, а также молодежь, относящаяся к возрастной группе от 23 до 29 лет (45,6\%). Вместе с тем на доброжелательность в качестве одного из важных воспитательных компонентов в целом указывается в $11,1 \%$ ответов опрошенных, но чаще об этом заявляют 40,0\% респондентов, у которых отсутствует опыт проявления собственной антипатии к представителям иных этнических групп по признаку национальной исклю- 
чительности, а также респонденты в возрасте от 18 до 22 лет (39,6 \%), представители азербайджанской $(66,1 \%)$ и лезгинской этнических групп $(47,4 \%)$, респонденты с доходом выше среднего (38,2\%), имеющие среднее специальное образование $(39,7 \%)$. Более $1 / 3$ участников исследования, указавших на единичный случай при ответе на вопрос «Были ли случаи, когда вы открыто выражали свое недовольство людьми определенной начиональности? ", считают, что в процессе воспитания ребенка важно уделять внимание формированию самоконтроля (40,9\%).

При этом в целом согласно нашему исследованию если столкнулись с недоброжелательным отношением к себе по поводу этнической принадлежности только 21,3\% респондентов, то доля респондентов, признавшая факты выражения собственной неприязни представителями иных этнических групп по признаку национальной исключительности в открытой форме, достигла более $1 / 3$ всех ответов (40,8\%). Между тем, несмотря на отсутствие в рамках социологической науки целостной, универсальной теории социального взаимодействия, мы, разделяя идею Е. Е. Кутявиной, исходили из допущения, что межэтнической будет интеракция, субъекты которой определяют себя либо партнера по взаимодействию как обладающего этническими чертами, связывают свои ожидания с этнической принадлежностью друг друга и соответствующим образом координируют свои действия (Кутявина, 2004).

Аля того чтобы иметь представления об интеграционном потенциале толерантных практик в российском обществе, мы предложили респондентам в обследуемых регионах оценить по семибалльной шкале, насколько важно для них, с одной стороны, сохранение мира между народами, а с другой - равенство прав и свобод человека. Рассчитав показатели среднего и соответствующие им значения стандартного отклонения, мы зафиксировали, что значения средних в достаточной степени хорошо представляют единогласие ответов анализируемой совокупности респондентов. Также выяснили, что сохранение мира между народами - мнение, получившее средний балл на уровне 6,32 (стандартное отклонение 1,118), имеет бо́льшую значимость и единодушие в представлениях опрошенных по сравнению с мнением о важности соблюдения равенства прав и свобод человека - там, где средний балл достиг отметки 5,93 (стандартное отклонение 1,35 , что свидетельствует о большей разнородности в распределении ответов) (табл. 2).

На актуальность в современных условиях сохранения мира в пределах нашего государства чаще указывают более $2 / 3$ респондентов старше 30 лет - 72,4\%, а также жители Республики Аагестан - 70,6\% и Ярославской области - 66,3\%. Оценивают степень важности реализации на практике равенства прав и свобод человека вне зависимости от национальной принадлежности на 7 баллов более других 63,9\% дагестанцев, 51,9\% респондентов со средним специальным и высшим образованием.

При анализе ответов респондентов на вопрос «Очените, пожалуйста, насколько вы чените в людях такие качества, как терпимость, воспитанность, доброжелательность» также по 7-балльной шкале мы обнаружили, что в межличностном взаимодействии опрошенные продемонстрировали наиболее весомые показатели и согласованность в ответах при оценке таких качеств, как воспитанность и доброжелательность (6,26 и 6,21 соответственно), по сравнению с таким качеством, как терпимость, 5,91 (табл. 3).

Заявили, что более всего ценят в людях воспитанность, представители армянской диаспоры, проживающие в Ярославской области, - 69,4\% наряду с респондентами полиэтничного Аагестана - 74,1\%. 
Таблища 2

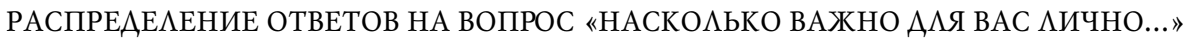
Table 2

DISTRIBUTION OF ANSWERS TO THE QUESTION "HOW IMPORTANT FOR YOU IS THE FOLLOWING...”

\begin{tabular}{|c|c|c|}
\hline \multicolumn{1}{|c|}{ Насколько важно для Вас лично... } & $\begin{array}{c}\text { Среднее значение } \\
\text { по 7-балльной } \\
\text { ощенке }\end{array}$ & $\begin{array}{c}\text { Стандартное } \\
\text { отклонение }\end{array}$ \\
\hline $\begin{array}{c}\text {...сохранение мира между народами в пределах } \\
\text { нашего государства? } \\
\text {...равенство прав и свобод человека независимо } \\
\text { от его национальности? }\end{array}$ & 6,32 & 1,118 \\
\hline
\end{tabular}

Терпимость как дичностное качество человека является наиболее значимым согласно мнению, во-первых, 56,6\% дагестанцев, среди которых чаще других отметили данную позицию представители кумыкской $(84,0 \%)$ и аварской $(66,1 \%)$ этнических групп; во-вторых - 63,6\% респондентов азербайджанской национальности, проживающих как в Аагестане, так и в Ярославской области. На доброжелательность в качестве важной характеристики указывают также респонденты со средним специальным образованием - 58,4\%.

Аля подбора эффективных социальных технологий и конструирования позитивных межэтнических взаимодействий и выявления особенностей формирования этнической толерантности важно понимать, в чем достаточно устойчиво проявляется сохранность этнического в современном обществе. Этим обусловлено изучение отличительных компонентов в структуре этноинтегрирующих признаков этнического самосознания населения регионов. Особенности воспроизведения обозначенных признаков определялись с помощью вопроса: «Как вы считаете, ито сближает ваш народ с другими народами России? " На лидирующих позициях в числе этноинтегрирующих факторов российских народов, в представлениях населения регионов, местожительство россиян (43,8\% респондентов), историческое судьба, прошлое народов $(40,5 \%$ опрошенных), язык $(33,1 \%)$, обычаи, традиции $(24,9 \%)$ и образ жизни $(23,0 \%)$. При этом местожительство, расположившееся на первой позиции в структуре этноин-

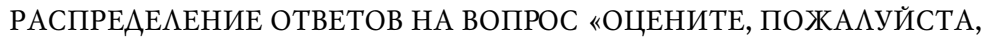

Таблища 3

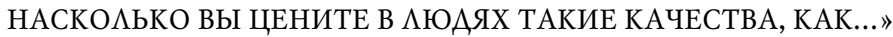

DISTRIBUTION OF ANSWERS TO THE QUESTION "PLEASE RATE HOW HIGHLY Table 3 YOU VALUE IN OTHERS THE FOLLOWING...”

\begin{tabular}{|l|c|c|}
\hline \multicolumn{1}{|c|}{ Насколько вы цените в людях... } & Среднее значение & $\begin{array}{c}\text { Стандартное } \\
\text { отклонение }\end{array}$ \\
\hline ...воспитанность & 6,26 & 1,019 \\
...доброжелательность & 6,21 & 1,094 \\
...терпимость & 5,91 & 1,244 \\
\hline
\end{tabular}


тегрирующих признаков, доминирует в ответах респондентов, принадлежащих к армянской диаспоре (53,7\%), проживающих в Ярославской области (48,8\%), а также среди опрошенных из числа среднедоходных групп населения $(47,6 \%)$. На язык чаще других обратили внимание малообеспеченные респонденты $(44,0 \%)$, опрошенные в полиэтничном Аагестане либо в Вологодской области (39,3 и 38,8\% соответственно), а также те участники исследования, которые старше 30 лет (37,3\%), являющиеся по этнической принадлежности кумыками $(72,0 \%)$, аварцами $(44,1 \%)$ либо русскими $(35,7 \%)$.

Отвечая на вопрос: «Как вы считаете, что сближает ваш народ с другими народами России?» - на образ жизни указывает практически каждый четвертый респондент, не имеющий личного опыта негативного межэтнического взаимодействия $(24,7 \%)$ либо не менее $1 / 3$ опрошенных, указавших на единичный случай демонстрации неприязни к людям по поводу национальной принадлежности $(32,8 \%)$, а также люди со средним специальным образованием $(26,9 \%)$.

Общую культуру как объединяющее свойство этносов на российских просторах позиционируют чаще других респонденты, этническая самоидентификация которых аварец (39,0\%) либо лезгин (37,8\%), проживающие в Аагестане $(31,1 \%)$ либо в Вологодской области $(20,2 \%)$, малообеспеченные люди $(24,5 \%)$, опрошенные с высшим образованием $(21,9 \%)$, а также женщины $(20,3 \%)$. Интеграционный потенциал исторического прошлого российских народов безоговорочен, так как дифференцированный анализ по данному признаку в разрезе основных социально-демографических групп не выявил значимых статистических различий.

Между тем комплекс представлений, образующих систему этнодифференцирующих признаков, вырабатывается на основе социальных представлений как о своей, так и о чужих этнических группах. К дифференцирующим факторам на основе этничности каждый второй респондент отнес в первую очередь обычаи и традичии (54,0\%), тогда как более $1 / 3$ опрошенных указали на такой признак, как язык $(46,6 \%)$ и почти четверть участников высказались за образ жизни в качестве разделяющего маркера (23,6\%). При ответе на вопрос: «В чем, по вашему мнению, основнье различия между вашим и другими народами России?» - в равной степени указали на принципиальные различия в чертах характера, психологии либо в модели поведения более $1 / 5$ респондентов (21,6 и 21,4\% соответственно).

В качестве разделяющего маркера обозначали обычаи и традиции чаще всего опрошенные, которые единожды столкнулись с недоброжелательным отношением к себе по поводу этнической принадлежности $(63,4 \%)$, а также те респонденты, что являются жителями Вологодской области (63,0\%) либо Аагестана $(59,9 \%)$. В образе жизни российских этносов скрываются основные различия согласно представлениям жителей полиэтничного социума $(30,6 \%)$, среди которых чаще данный вариант звучал от аварцев $(37,9 \%)$, лезгин $(29,7 \%)$ либо кумыков $(28,0 \%)$; респондентов, идентифицирующих себя с русским этносом $(25,9 \%)$. На потенциальные возможности языковых различий в качестве дифференциации народов обратили внимание более других аварцы $(58,6 \%)$, респонденты со средним образованием $(57,9 \%)$, жители многонациональной республики $(53,6 \%)$ либо Вологодского региона $(52,3 \%)$.

Чувство кровного родства является разделяющим фактором согласно мнению 12,7\% жителей Ярославской области. На антропологические признаки (Внешность) при ответе на вопрос: «В чем, по вашему мнению, основные различия между вашим и другими народами России?» - указали опрошенные со средним образованием (22,7\%), высокообеспеченные $(23,4 \%)$, а также опрошенные, признавшие наличие в личной би- 
ографии единичного случая столкновения с недоброжелательным отношением к себе на основе национальной исключительности $(28,7 \%)$.

Религию к числу разъединяющих факторов во взаимоотношениях между народами отнесли кумыки (32,0\%), лезгины (32,4\%), малообеспеченные респонденты $(23,6 \%)$ либо жители Вологодской области $(21,0 \%)$. В числе респондентов, признавших неоднократные факты выражения собственной неприязни по отношению к представителям иных этносов, либо среди высокообразованных практически $1 / 3$ считает, что в качестве основных этнодифференцирующих признаков российских народов выступают несхожие черты характера, психология этнических групп $(28,5$ и $27,4 \%$ соответственно) либо модель поведения (28,5\%).

Размышляя над обозначенным нами вопросом, на отличия в историческом прошлом указывают более других опрошенные, имевшие негативный опыт межэтнического взаимодействия, т. е. многократно сталкивавшиеся с антипатией в отношении себя по национальному признаку, $(21,0 \%)$ либо армяне $(19,4 \%)$.

\section{ОБСУЖАЕНИЕ РЕЗУ АЬТАТОВ ИССАЕАОВАНИЯ}

Реализация задачи, нацеленной на выявление перспективных возможностей социализации подрастающего поколения на основе принципов, формирующих основу толерантных взаимодействий, позволила зафиксировать мнение респондентов о том, что чаще всего необходимо акцентировать внимание в процессе социализации на воспитании честности $(21,3 \%)$, трудолюбия $(16,3 \%)$, а также вежливости $(14,6 \%)$ и уважения к Аругим людям $(14,2 \%)$.

Анализ опыта межэтнического взаимодействия респондентов - жителей Ярославской, Вологодской областей, а также полиэтничого Аагестана (2013-2014) - обнаружил: в течение указанного периода каждый пятый в числе опрошенных столкнулся с недоброжелательным отношением к себе по поводу собственной этнической принадлежности, тогда как доля респондентов, признавшая факты выражения личной неприязни представителями иных этнических групп по признаку национальной исключительности в открытой форме, достигла 40,8\% всех ответов. Предполагаем, что весомая разница в ответах на вопросы о наличии либо отсутствии негативного опыта межэтнического взаимодействия, возможно, свидетельствует, с одной стороны, о завышенной демонстративности респондентами собственной модели поведения, свидетельствующей об эфемерной смелости в проявлении открытой неприязни по национальному признаку, а с другой - таит в себе нежелание определенной части опрашиваемых сделать достоянием гласности дискриминационное отношение в свой адрес на основе этнических различий.

Рассмотрение интеграционного потенциала толерантных практик как совокупности действий и норм поведения, направленных на реализацию возможности объединения представителей разных этнических групп, а также их самоидентификации как членов социума в российском обществе, позволило выяснить: сохранение мира между народами в пределах нашего государства имеет относительно бо́льшую значимость в представлениях опрошенных по сравнению с важностью соблюдения равенства прав и свобод человека независимо от его национальности. Вместе с тем в межличностном взаимодействии опрошенные считают более важными для человека такие качества, как воспитанность и доброжелательность, по сравнению с терпимостью.

В числе этноинтегрирующих факторов российских народов в представлениях населения регионов территориальньй признак (43,8\% респондентов), историческая 
судьба, прошлое народов (мнения 40,5\% опрошенных), язык (33,1\%), объиаи, традиции $(24,9 \%)$ и образ жизни (23,0\%). Стоит отметить, что, по нашему мнению, роль общности исторической судьбы как символа единства народа в современных условиях возрастает на фоне унификации этнических культур наряду с неуклонным сокращением количества этнодифференцирующих признаков. В целом полученные данные можно проинтерпретировать следующим образом: для общероссийской консолидации в структуре сближающих факторов в самосознании жителей регионов преобладают очевидные, объективные этноинтегрирующие признаки (в частности, место жительства, историческое прошлое народов, язык). К дифференцирующим факторам на основе этничности опрошенные отнесли обычаи и традииии (54,0\%), языюк $(46,6 \%)$, образ жизни $(23,6 \%)$, а также отличия в чертах характера, психологии либо в модели поведения (21,6 и 21,4\% соответственно). Аналогичные мнения на основе исследований, проведенных в других российских регионах, высказывают Ч. К. Аамажаa, Е. М. Воробьев (Аамажаа, Хайруллина, 2015; Хайруллина, Воробьев, 2014).

\section{ЗАКАЮЧЕНИЕ}

На основе историко-теоретического обзора сущности толерантности в социологической теории мы можем отметить, что интерпретация данного феномена прошла путь от концепции отчуждения в качестве источника социальной интолерантности до трактовки изучаемого концепта как ценности и социальной нормы современного гражданского общества. При этом необходимо учитывать многогранное, амбивалентное и динамичное содержание понятия «толерантность». В этой связи мы определяем этническую толерантность как систему норм социального взаимодействия и отношений к различным проявлениям социально-культурного разнообразия, регулирующих социальные связи в различных сферах жизни общества. Мы представили конкретные социологические данные, характеризующие проблемы и особенности, детерминирующие реализацию этнической толерантности в малых социальных группах в условиях моно- и полиэтничного социумов.

Аля решения современных проблем в сфере межэтнических отношений и расширения конструктивных толерантных практик целесообразной представляется реализация следующих мероприятий:

- проведение дальнейшего усовершенствования нормативно-правовой базы, необходимой для реализации поставленных задач в области регулирования этнонациональных отношений и национальной политики государства, его отдельных субъектов (регионов) и муниципальных образований;

- популяризация культурного наследия страны, а также обеспечение и соблюдение преемственности воздействия пропаганды средствами и силами как первичных, так и вторичных агентов социализации (семьи, образовательных учреждений, трудовых коллективов, СМИ);

- регулярная и систематичная реализация информационно-пропагандистских мероприятий в сфере укрепления единства российской нации и этнокультурного развития народов;

- организация и сочетание этнокультурной, воспитательной деятельности с работой на производстве, в учебном заведении, с деятельностью в волонтерских / общественных организациях;

- популяризация межнационального сотрудничества, укрепление гражданского единства среди различных категорий и групп населения. 


\section{СПИСОК АИТЕРАТУРЫ}

Абельс, Х. (1999) Интеракция, идентификация, презентация. Введение в интерпретативную социологию : пер. с нем. / под общ. ред. Н. А. Головина и В. В. Козловского. СПб. : Алетейя. 261 с.

Бауман, 3. (2002) Индивидуализированное общество : пер. с англ. / под ред. В. А. Иноземцева. М. : Могос. 324 с.

Галкин, А. А., Красин, Ю.А. (2003) Культура толерантности перед вызовами глобализации // Социологические исследования. № 8. С. 64-74.

Аробижева, А. М. (2009) Толерантность и проблемы интеграции многокультурных сообществ // Вестник Института Кеннана в России. Вып. 16. С. 16-28.

Козер, А. А. (2006) Мастера социологической мысли. Идеи в историческом и социальном контексте / пер. с англ. Т. И. Шумилиной ; под ред. И. Б. Орловой. М. : Норма. 513 с.

Кузнецов, И. М. (2003) Многообразие этнокультурных миров // Социология межэтнической толерантности / отв. ред. М. М. Аробижева. М. : Изд-во Института социологии РАН. 222 с. C. $112-135$.

Кули, Ч. Х. (2000) Человеческая природа и социальный порядок. М. : Идея-пресс ; Аом интеллектуальной книги. 309 с.

Кутявина, Е. Е. (2004) Проблема изучения межэтнического взаимодействия // Вестник Нижегородского университета им. Н. И. Аобачевского. Серия: Социальные науки. Вып. 1 (3). С. 212-220.

Мамажаа, Ч. К., Хайруллина, Н. Г. (2015) Архаизация и неотрадиционализм в регионах Уральского федерального округа // Знание. Понимание. Умение. № 1. С. 29-38. DOI: 10.17805/ zрu.2015.1.3

Иебедева, О. В. (2010) Теоретические аспекты толерантности и ее преломление в практике дипломатических отношений. М. : МГИМО-Университет. 150 с.

Маркс, К. (2000) Экономическо-философские рукописи 1844 года // Маркс, К. Социология : сб. М. : Канон-пресс-Ц ; Кучково поле. 432 с. С. 177-324.

Мацковский, М. (2001) Толерантность как объект социологического исследования [Электронный ресурс] // Век толерантности. № 3-4. URL: http://tolerance.ru/VT-3-4-toler-kak. php?PrPage=VT [архивировано в WebCite] (дата обращения: 11.05.2015).

Мертон, Р. (1994) Явные и латентные функции // Американская социологическая мысль / под ред. В. И. Аобренькова. М. : ИзА-во МГУ. 496 с. С. 379-448.

Мид, Аж. Г. (2009) Избранное : сб. переводов / сост. и перев. В. Г. Николаев ; отв. ред. А. В. Ефременко. М. : ИНИОН. 290 с.

Образован Совет по межнациональным отношениям. (2012) [Электронный ресурс]// Президент России. Официальный сайт. 7 июня. URL: http://kremlin.ru/events/president/news/15577 [архивировано в WebCite] (дата обращения: 04.07.2015).

Общественное мнение - 2013. (2014) М. : Аевада-Центр. 252 с. URL: http://levada.ru/books/ obshchestvennoe-mnenie-2013 [архивировано в WebCite] (дата обращения: 01.05.2015).

Панина, Н. В., Головаха, Е. И. (2006) Национальная толерантность и идентичность в Украине: опыт применения шкалы социальной дистанции в мониторинговом социологическом исследовании // Социологический журнал. № 3-4. С. 102-126.

Парк, Р. (2011) Избранные очерки : сб. переводов / сост. и пер. с англ. В. Г. Николаев ; отв. ред. А. В. Ефременко. М. : ИНИОН. 320 с.

Петров, В. Н. (2003) Этнические мигранты и полиэтничная принимающая среда: проблемы толерантности // Социологические исследования. № 7. С. 84-91.

Победа, Н. А. (2007) Толерантность: содержательные смыслы и социологическая интерпретация // Социологические исследования. № 6. С. 13-28.

Подписан Указ о Стратегии государственной нацполитики России до 2025 года. (2012) [Электронный ресурс]// Президент России. Официальный сайт. 19 декабря. URL: http://kremlin.ru/ news/17165 [архивировано в WebCite] (дата обращения: 29.05.2015).

Поручение по вопросу создания Федерального агентства по делам национальностей. (2015) [Электронный ресурс] // Президент России. Официальный сайт. 13 марта. http://kremlin.ru/ events/president/news/47849 [архивировано в WebCite] (дата обращения: 17.03.2015). 
Постановление Правительства РФ от 20 августа 2013 г. № 718 «О федеральной целевой программе "Укрепление единства российской нации и этнокультурное развитие народов России (2014-2020 гг.)”». (2013) [Электронный ресурс]// Правительство России. URL: http://government. $\mathrm{ru} / \mathrm{media} /$ files/41d4862001ad2a4e5359.pdf [архивировано в WebCite] (дата обращения: 08.05.2015).

Постановление Правительства РФ от 15 апреля 2014 г. №307 «Об утверждении государственной программы Российской Федерации "Региональная политика и федеративные отношения” ». (2014) [Электронный ресурс]// Правительство России. URL: http://government.ru/docs/ all/91154/ [архивировано в WebCite] (дата обращения: 06.05.2015).

Распоряжение Правительства РФ от 15 июля 2013 г. № 1226-р. (2013) [Электронный ресурс]// Правительство России. URL: http://government.ru/media/files/41d47a99d97a4ea0ebf3.pdf [архивировано в WebCite] (дата обращения: 08.05.2015).

Рыжова, С. В. (2008) Этническая и гражданская идентичность в контексте межэтнической толерантности : автореф. дис. ... канд. социол. наук. М. 33 с.

Сорокин, П. А. (1992) Человек. Цивилизация. Общество : пер. с англ. / под общ. ред. А. Ю. Согомонова. М. : Политиздат. 543 с.

Тишков, В. А. (2003) Реквием по этносу: исследования по социально-культурной антропологии. М. : Наука. 543 с.

Указ Президента РФ от 31 марта 2015 г. № 168 «О Федеральном агентстве по делам национальностей». (2015) [Электронный ресурс] // Президент России. URL: http://kremlin.ru/acts/ bank/39565 [архивировано в WebCite] (дата обращения: 08.05.2015).

Хайруллина, Н. Г., Воробьев, Е. М. (2014) Межэтнические отношения в Тюменской области: динамика и тенденции. Тюмень : ТюмГНГУ. 196 с.

Аата поступления: 10.06 .2015 2.

\section{MANIFESTATIONS OF ETHNIC TOLERANCE IN SMALL SOCIAL GROUPS \\ IN RUSSIA'S MONO-AND POLYETHNIC REGIONS \\ N. S. GADZHIGASANOVA \\ (P.G. DEMIDOV YAROSLAVL STATE UNIVERSITY) \\ N. G. KHAIRULLINA \\ (TYumen State OIL AND GAS UNIVERSITY)}

The population of the Russian Federation has a multi-ethnic structure, which includes over 180 large ethnicities and numerous smaller ethnic groups. One of the most important conditions for longterm development of a multicultural society is peaceful coexistence of ethnic groups and their representatives. This determines the need for and the importance of cultural expression of ethnic tolerance among all peoples of Russia, thus making the scientific study of the problem of tolerance. The article is devoted to the description and analysis of ethno-national relations and public policy in this area.

Russia's legislation in the field of regulating interethnic relations has developed to include significant innovations. Among the documents adopted and implemented are the Strategy of State Ethnic Policy in the Russian Federation until 2025 (and its action plan for the years 2013-2015), the Federal target program "Strengthening the Unity of the Russian Nation and the Ethnic and Cultural Development of the Peoples of Russia (2014-2020)" and others.

These documents have laid the corner stone for the contemporary ethnic and national policies aimed at achieving long-term results. At the same time they suffer from fragmentation and are in need of coordinating their main objectives, directions and most efficient methods and mechanisms of implementation.

The article presents the results of a sociological study "Peculiarities of Ethnic Tolerance in Monoand Polyethnic Regions of Russia" carried out by the authors in January - October 2014 in Yaroslavl and Vologda Oblasts, as well as in the Republic of Dagestan.

To solve the current problems in the sphere of interethnic relations, we need to improve the fundamental provisions of legal acts covering and guiding the state ethnic policy of the Russian Fede- 
ration. Also required is profound analysis of the key indicators of how well the regional and municipal legislations of the constituent subjects of the Russian Federation comply with the main legal provisions at the federal level. Promotion of cultural heritage and other suchlike programs can also be of use.

Keywords: ethnic tolerance, inter-ethnic cooperation, ethnic policy.

\section{REFERENCES}

Abels, H. (1999) Interaktsiia, identifikatsiia, prezentatsia. Vvedenie v interpretativnuiu sotsiologiiu [Interaction, identification, presentation. Introduction to interpretative sociology] : transl. from German / ed. by N. A. Golovin and V. V. Kozlovskiy. St. Petersburg, Aletheia Publ. 261, [4] p. (In Russ.).

Bauman, Z. (2002) Individualizirovannoe obshchestvo [Individualized society]/ ed. by V. L. Inozemtsev. Moscow, Logos Publ. LXIII, 324, [2] p. (In Russ.).

Galkin, A. A. and Krasin, Yu. A. (2003) Kul'tura tolerantnosti pered vyzovami globalizatsii [The culture of tolerance facing the challenges of globalization]. Sotsiologicheskie issledovaniia, no. 8, pp. 64-74. (In Russ.).

Drobizheva, L. M. (2009) Tolerantnost' i problemy integratsii mnogokul'turnykh soobshchestv [Tolerance and problems of integrating multicultural communities]. Vestnik Instituta Kennana $v$ Rossii, vol. 16, pp. 16-28. (In Russ.).

Coser, L. A. (2006) Mastera sotsiologicheskoi mysli. Idei v istoricheskom i sotsial' nom kontekste [Masters of sociological thought. Ideas in historical and social context]/ transl. by. T. I. Shumilina ; ed. by I. B. Orlova. Moscow, Norma Publ. 513 p. (In Russ.).

Kuznetsov, I. M. (2003) Mnogoobrazie etnokul'turnykh mirov [The variety of ethnocultural words]. In: Sotsiologiia mezhetnicheskoi tolerantnosti [The sociology of interethnic tolerance]/ ed. by L. M. Drobizheva. Moscow, Publ. House of the Institute of Sociology, RAS. 222 p. Pp. 112-135. (In Russ.).

Cooley, Ch. H. (2000) Chelovecheskaia priroda $i$ sotsial'nyi poriadok [Human nature and the social order]. Moscow, Ideia-press ; Dom intellektual'noi knigi Publ. 309 p. (In Russ.).

Kutyavina, E. E. (2004) Problema izucheniia mezhetnicheskogo vzaimodeistviia [The issue of studying interethnic relations]. Vestnik Nizhegorodskogo universiteta im. N. I. Lobachevskogo. Seriia: Sotsial' nye nauki, vol. 1 (3), pp. 212-220. (In Russ.).

Lamazhaa, Ch. K. and Khairullina, N. G. (2015) Arkhaizatsiia i neotraditsionalizm v regionakh Ural'skogo federal'nogo okruga [Archaization and neo-traditionalism in the regions of the Ural Federal District]. Znanie. Ponimanie. Umenie, no. 1, pp. 29-38. (In Russ.). DOI: 10.17805/zpu.2015.1.3

Lebedeva, O. V. (2010) Teoreticheskie aspekty tolerantnosti $i$ ee prelomlenie $v$ praktike diplomaticheskikb otnoshenii [Theoretical aspects of tolerance and its interpretation in the practice of diplomatic relations]. Moscow, MGIMO-Universitet Publ. 150, [1] p. (In Russ.).

Marx, K. (2000) Ekonomichesko-filosofskie rukopisi 1844 goda [Economic and philosophical manuscripts of 1844]. In: Marx, K. Sotsiologiia [Sociology] : Collected works. Moscow, Kanon-press-C ; Kuchkovo pole Publ. 432 p. Pp. 177-324. (In Russ.).

Matskovskii, M. (2001) Tolerantnost' kak ob'ekt sotsiologicheskogo issledovaniia [Tolerance as an object of sociological research]. Vek tolerantnosti, no. 3-4. [online] Available at: http://tolerance. $\mathrm{ru} /$ VT-3-4-toler-kak.php?PrPage=VT [archived in WebCite] (accessed 11.05.2015). (In Russ.).

Merton, R. (1994) Iavnye i latentnye funktsii [Manifest and latent functions]. In: Amerikanskaia sotsiologicheskaia mysl' [American sociological thought] / ed. by V. I. Dobren'kov. Moscow, Moscow State University Publ. 496 p. Pp. 379-448. (In Russ.).

Mead, J. H. (2009) Izbrannoe [Selected works] : Translations / transl. by V. G. Nikolaev, ed. by D. V. Efremenko. Moscow, INION Publ. 290 p. (In Russ.).

Obrazovan Sovet po mezhnatsional'nym otnosheniiam [Council on Ethnic Relations established]. (2012) Prezident Rossii. Ofitsial'nyi sait. June 7. [online] Available at: http://kremlin.ru/events/ president/news/15577 [archived in WebCite] (accessed 4.07.2015). (In Russ.). 
Obshbestvennoe mnenie - 2013 [Public Opinion - 2013]. (2014) Moscow, Levada-Tsentr. 252 p. [online] Available at: http://levada.ru/books/obshchestvennoe-mnenie-2013 [archived in WebCite] (accessed 1.05.2015). (In Russ.).

Panina, N. V. and Golovakha, E. I. (2006) Natsional'naia tolerantnost' i identichnost' v Ukraine: opyt primeneniia shkaly sotsial'noi distantsii $\mathrm{v}$ monitoringovom sotsiologicheskom issledovanii [Tolerance and national identity in Ukraine: Using the social distance scale in for monitoring sociological study]. Sotsiologicheskii zhurnal, no. 3-4, pp. 102-126. (In Russ.).

Park, R. (2011) Izbrannye ocberki [Selected essays]: Translations / transl. by V. G. Nikolaev; ed. by D. V. Efremenko. Moscow, INION Publ. 320 p. (In Russ.).

Petrov, V. N. (2003) Etnicheskie migranty i poliietnichnaia prinimaiushhaia sreda: problemy tolerantnosti [Ethnic migrants and polyethnic host environment: Problems of tolerance]. Sotsiologicheskie issledovaniia, no. 7, pp. 84-91. (In Russ.).

Pobeda, N. A. (2007) Tolerantnost': soderzhatel'nye smysly i sotsiologicheskaia interpretatsiia [Tolerance: Content and sociological interpretation]. Sotsiologicheskie issledovaniia, no. 6, pp. 13-28. (In Russ.).

Podpisan Ukaz o Strategii gosudarstvennoi natspolitiki Rossii do 2025 goda [Decree on Strategy of State Ethnic Policy until 2025 signed]. (2012) Prezident Rossii. Ofitsial'nyi sait. December 19. [online] Available at: http://kremlin.ru/news/17165 [archived in WebCite] (accessed 29.05.2015). (In Russ.).

Poruchenie po voprosu sozdaniia Federal'nogo agentstva po delam natsional'nostei [Commission to establish Federal Agency for Nationalities]. (2015) Prezident Rossii. Ofitsial'nyi sait. March 13. [online] Available at: http://kremlin.ru/events/president/news/47849 [archived in WebCite] (accessed 17.03.2015). (In Russ.).

Postanovlenie Pravitel’stva RF ot 20 avgusta 2013 g. № 718 «O federal’noi tselevoi programme "Ukreplenie edinstva rossiiskoi natsii i etnokul'turnoe razvitie narodov Rossii (2014-2020 gg.)” " [Cabinet of Ministers of the Russian Federation, Directive No. 718 "On the Federal Target Program «Strengthening the Unity of the Russian Nation and Ethnic and Cultural Development of the Peoples of Russia (2014-2020)»", August 20, 2013]. (2013) Pravitel'stvo Rossii [online] Available at: http://government.ru/media/files/41d4862001ad2a4e5359.pdf [archived in WebCite] (accessed 8.05.2015). (In Russ.).

Postanovlenie Pravitel'stva RF ot 15 aprelia 2014 g. № 307 «Ob utverzhdenii gosudarstvennoi programmy Rossiiskoi Federatsii "Regional'naia politika i federativnye otnosheniia"» [Cabinet of Ministers of the Russian Federation, Directive No. 307 "On Approval of the State Program of the Russian Federation «Regional Policy and Federal Relations»", April 15, 2014]. (2014) Pravitel'stvo Rossii [online] Available at: http://government.ru/docs/all/91154/ [archived in WebCite] (accessed 6.05.2015). (In Russ.).

Rasporiazhenie Pravitel'stva RF ot 15 iiulia 2013 g. № 1226-r [Cabinet of Ministers of the Russian Federation, Executive order No. 1226-p, July 15, 2013]. (2013) Pravitel'stvo Rossii [online] Available at: http://government.ru/media/files/41d47a99d97a4ea0ebf3.pdf [archived in WebCite] (accessed 8.05.2015). (In Russ.).

Ryzhova, S. V. (2008) Etnicheskaia i grazhdanskaia identichnost' $v$ kontekste mezhetnicheskoi tolerantnost $i$ [Ethnic and civic identity in the context of inter-ethnic tolerance] : Abstract of Diss.... Candidate of Sociology. Moscow. 33 p. (In Russ.).

Sorokin, P. A. (1992) Chelovek. Tsivilizatsiia. Obshchestvo [Man. Civilization. Society]/ ed. by A. Yu. Sogomonov. Moscow, Politizdat Publ. 543 p. (In Russ.).

Tishkov, V. A. (2003) Rekviem po etnosu: issledovaniia po sotsial' no-kul' turnoi antropologii [Requiem for the ethnos: Studies in socio-cultural anthropology]. Moscow, Nauka Publ. 543 p. (In Russ.).

Ukaz Prezidenta $R F$ «O Federal' nom agentstve po delam natsional' nostei» ot 31 marta $2015 \mathrm{~g}$. № 168 [President of the Russian Federation, Decree No. 168 "On the Federal Agency for Nationalities”, March 31, 2015]. (2015) Prezident Rossii. Ofitsial' nyi sait [online] Available at: http://kremlin.ru/acts/bank/39565 [archived in WebCite] (accessed 8.05.2015). (In Russ.). 
Khairullina, N. G. and Vorobiev, E. M. (2014) Mezhetnicheskie otnosheniia v Tiumenskoi oblasti: dinamika i tendentsii [Interethnic relations in Tyumen Oblast: Dynamics and trends]. Tyumen, Tyumen State Oil and Gas University Publ. 196 p. (In Russ.).

Submission date: 10.06 .2015$.

Гаджигасанова Наиде Сефтеровна - кандидат социологических наук, старший преподаватель кафедры социологии Ярославского государственного университета им. П. Г. Аемидова. Aдрес: 150000, Россия, г. Ярославль, ул. Советская, А. 10. Тел.: +7 (4852) 32-96-05. Эл. адрес: nаide27@mail.ru

Хайруллина Нурсафа Гафуровна - доктор социологических наук, профессор, заведующая кафедрой социальных наук Тюменского государственного нефтегазового университета, членкорреспондент Сибирской академии наук высшей школы, академик Региональной академии менеджмента Президента Казахстана. Адрес: 625000, Россия, г. Тюмень, ул. Володарского, д. 38. Тел.: +7 (3452) 45-35-26. Эл. адрес: nur@tsogu.ru

Gadzhigasanova Naide Sefterovna, Candidate of Sociology, Senior Lecturer, Department of Sociology, P. G. Demidov Yaroslavl State University. Postal address: 10 Sovetskaya St., 150000 Yaroslavl, Russian Federation. Tel.: +7 (4852) 32-96-05. E-mail: naide27@mail.ru

Khairullina Nursafa Gafurovna, Doctor of Sociology, Professor and Chair, Department of Social Sciences, Tyumen State Oil and Gas University; Corresponding member, Siberian Academy of Higher School Sciences; Member, Regional Academy of Management of the President of Kazakhstan. Postal address: 38 Volodarsky St., 625000 Tyumen, Russian Federation. Tel.: +7 (3452) 45-35-26. E-mail: nur@tsogu.ru 